\title{
Impacts of submarine groundwater discharge on Kuwait Bay
}

\author{
M. Al-Senafy \& A. Fadlelmawla \\ Water Research Center, Kuwait Institute for Scientific Research, Kuwait
}

\begin{abstract}
The flow of groundwater into the sea, which is known as submarine groundwater discharge (SGD), is an important phenomenon that takes place at the interface between inland groundwater and the sea. The importance of this phenomenon arises from its proven impact on the chemistry of coastal waters. In efforts to support sound management of Kuwait bay, this study was carried out to obtain knowledge on one of the significant elements of the nutritional budget of the bay, that is, the SGD. The study adopted the use of naturally occurring radium isotopes as tracers to quantify the SGD to the bay. A total of 12 sampling campaigns were conducted resulting in the collection of 176 seawater samples. These samples were collected for oceanographic characterization of the bay water, determination of radium content, and determination of trace elements content as ancillary information. Two groundwater sampling campaigns were conducted resulting in collecting 48 radium samples, 45 major elements samples and 23 trace elements samples. Signs for SGD impacts on the characteristics of the bay were examined by looking into temporal and spatial correlations between 226Ra activities and bay water characteristics. Overall, temperature, nitrate and chlorophyll-a showed temporal and spatial trend similar to radium. It is recommended to conduct an overall budgeting of the bay's nutritional and elemental inputs and outputs in order to reduce the impacts of SGD.

Keywords: radium, Arabian Gulf, nutritional budget, sea.
\end{abstract}

\section{Introduction}

As groundwater flows down gradient, it flows directly into the sea wherever a coastal aquifer is connected to the sea creating the submarine groundwater discharge (SGD). 
While the magnitude of SGD may be relatively minor, i.e., compared to the volume of the receiving water body, recent studies have indicated its significance [1-6]. This significance stemmed from the fact that the chemical and biological composition of the groundwater is inherently different from the receiving resource making the impact on the chemistry of the coastal waters often profound. At the interface of sea/land, there are a number of processes taking place, typically simultaneously. Due to pressure head differences, groundwater flows into the sea (i.e., if geological conditions allow). Simultaneously, the two water-bodies exchange salts extensively through advective and diffusive forces until pseudo-equilibrium are reached, creating an inland interface zone between the fresh and saline waters. The location of this interface depends, in the long term, on the salinity and pressure differences between the two waters. In the short term, the interface intrudes farther inland and recedes beyond its equilibrium location on daily bases due to tidal fluctuations. This continuous interaction has serious consequences on both resources due to the extensive mass exchange that takes place as a result of mixing, diffusion, and desorption of nutrients from inland solid phases during tides-driven intrusions/recedes (recirculation). Therefore, studies aimed at understanding chemical fluxes to the coastal zone derived from SGD must consider both groundwater and recirculated seawater, which has implications on the selection of the evaluation approach. Although salinity may be used as a tracer of fresh SGD, brackish and saline SGD fluxes, as in the case of Kuwait, require the use of different tracer. Investigations using stable and radioactive isotopes have enabled the study of the various aspects of SGD [7]. While estimates of SGD using this approach, similar to the other two approaches, suffer from different sources of uncertainties, this approach remains the most promising for estimating the SGD-driven nutrients input to the coastal area since it is the only one that accounts for the nutrients input by re-circulated seawater [2, 8-11]. The most suitable approach for assessing the nutritional input to the (Kuwait Bay) $\mathrm{KB}$ is the use of radioactive tracer. Among the radioactive isotopic tracers, radium has been proven to be a useful tracer of total SGD in many environments on both small and large scales from salt marshes (e.g., [12]) to the continental shelf [2].

\section{Study area}

$\mathrm{KB}$ is an elliptically shaped embayment that protrudes from the Arabian Gulf in the westward direction at its northwestern corner (Fig. 1). It covers an area of about $880 \mathrm{~km}^{2}$; with a shoreline length of $192 \mathrm{~km}$. KB is relatively shallow with water depths not exceeding $20 \mathrm{~m}$ in most of the Bay (Fig. 1). The southern part of the bay is deeper than the northern part with the deepest section at the entrance of the bay. Many sections along the bay have wide tidal flats with large areas that get dry during ebb tides. The tides in the bay are semidiurnal, with two high tides and two low tides occurring within a lunar day. The maximum range between the highest and lowest tidal levels reaches about $4.0 \mathrm{~m}$ as provided in [13]. Currents in KB are mainly induced by tide, although wind is considered to be a secondary driving force. The waves in the Bay are either locally generated 
by northwesterly winds or travel into the Bay after being generated in the Arabian Gulf by southeasterly winds. The wave conditions in KB will not exceed 1.5-m height [13]. The Sulaibikhat Bay, a smaller bay within the southern parts of KB, ranks among the Arabian Gulf's most biologically productive areas [14]. The southern shoreline of the bay, on the other hand, is highly developed as a metropolitan and commercial area, and has been modified, with more than 638 ha of land reclaimed and more than 210 ha of area dredged [14]. Two main ports are located in KB, Shuwaikh and Doha ports. In addition, there are three desalination and/or power generation plants in $\mathrm{KB}$, several recreation sites, sewage outlets, and one mariculture site off Doha (operation was severely impacted in 1999 due to an extensive harmful algal bloom, as well as bacterial pathogen infection of marine fish in 2001 causing complete kill of the cultured fish) [15] and [16]. In addition, KB waters are influenced by the lower salinity and nutrient-rich discharge from Shatt Al-Basrah Channel and Shatt Al-Arab River, especially during the spring period when the Shatt Al-Arab River flow is at its peak. Despite all the developments, KB remains one of the country's most valuable and productive nurseries for marine species of commercial importance. $\mathrm{KB}$ and its associated mudflats have been internationally recognized as an important nursery habitat requiring protection. The seawater temperature range for $\mathrm{KB}$ is $11.9^{\circ} \mathrm{C}$ (winter) to $36^{\circ} \mathrm{C}$ (in summer), contributing to a seasonal difference in seawater temperature of $25^{\circ} \mathrm{C}$ [14]. The transparency of KB waters ranges from $0.45-4 \mathrm{~m}$, while turbidity ranges from 5.0-40 NTU, but increases toward the northern entrance of the bay. The following ranges of nutrient concentrations were reported for KB: ammonia (undetectable concentration -30.3 $\mu \mathrm{g}$-at $/ \mathrm{l}$; the higher values were reported in waters close to sewage outfalls),

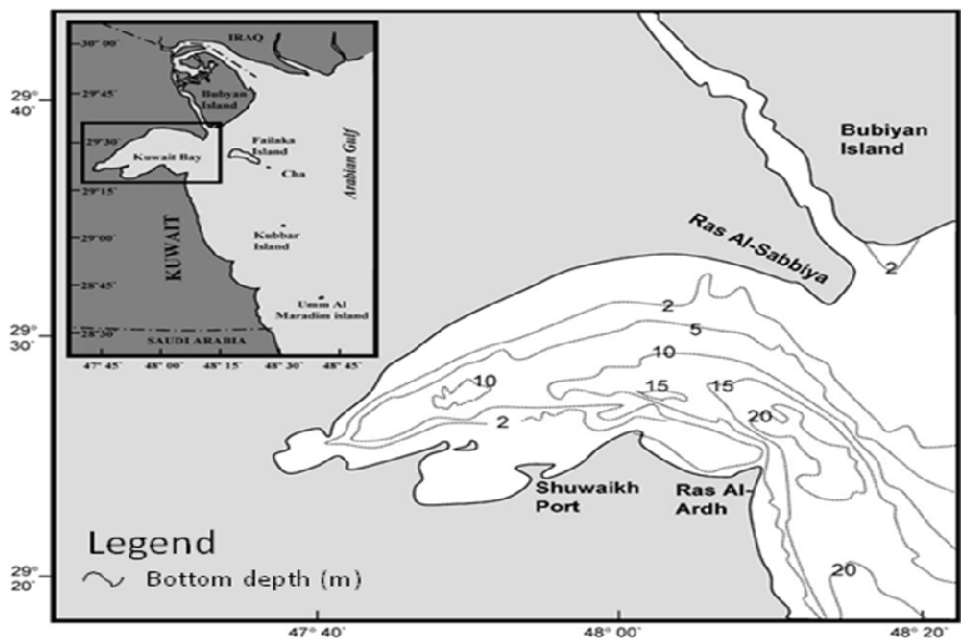

Figure 1: $\quad$ Depth (m below sea level) of KB bottom (source: [17]). 
nitrates (undetectable -27.1 $\mu \mathrm{g}$-at/1), phosphates (undetectable ->1.0 $\mu \mathrm{g}$-at/l; higher values near sewage outfalls), and silicates $(9.0->20 \mu \mathrm{g}$-at/l). KB is productive with a range of chlorophyll- $a$ concentration of $1->5 \mu \mathrm{g} / 1$.

Extremely high temperatures, as well as short mild winters, high number of sunshine hours, low humidity and generally dry conditions are essentially the main characteristics of the climate at the study area [18]. The average annual rainfall, as recorded at the Kuwait City Airport, between 1963 and 2002 was $113.9 \mathrm{~mm}$. Evaporation ranged between 146 and $961 \mathrm{~mm}$ in January and July, respectively. A very relevant feature of the weather in Kuwait is the common intense dust storms. The relevance of this phenomenon, which is more frequent during summer, comes from the fact that, as these storms are so severe; they contribute significantly to the transport of sedimentary debris to the bay [19]. Such fresh debris can present a significant source for radium that should be taken into account in constructing the radium budget over the bay.

\section{Methodology}

The field activities of this study were directed in two channels, sampling and groundwater wells drilling. A total of 12 seawater sampling campaigns were conducted resulting in the collection of 176 seawater samples from 10 sampling stations (Fig. 2). These samples were collected for oceanographic characterization of the bay water, determination of radium content for mass balance calculations, and determination of trace elements content as ancillary information. The spatial distribution of the stations is based on an even coverage of the bay. The oceanographic sampling covered all seasons of the year.

Surface and bottom water samples were collected by dropping the Niskin bottle into the water and taking samples from different depths starting with surface, middle and bottom (depending on water column depth at each station). The Niskin bottle was pulled up from the sea, and the water sample obtained was transferred into special bottles. For the purpose of conducting radium mass balance for the bay water, three separate sampling campaigns were conducted to provide samples for radium and trace elements analysis (one campaign only). The campaigns were spread over nearly one year period to cover potential seasonal changes. Sampling locations were dictated by the need of having an average radium concentration over the bay.

A total of 18 existing wells were selected for sampling. In addition to being functional, the main criteria for selecting those wells were the closeness to the shoreline and the shallow depth. As the existing wells had spatial coverage gaps, additional set of wells (10 wells) were drilled to cover those gaps. Accordingly, the first sampling round was conducted for the 18 existing wells, while the second round covered all the 28 wells (Fig. 3). All together, 48 radium samples, 45 major elements samples and 23 trace elements samples were collected.

Groundwater and seawater samples were analyzed for a wide range of parameters, which required the involvement of three laboratories namely; KISR's Central Analytical Laboratory; Water Research Center Laboratory; the Aquaculture, Fisheries, and Marine Environment Department laboratories, and 
Duke University Laboratories, USA. Essentially, the local laboratories covered, with intentional overlaps, major anions and cations, trace elements, nitrogen compounds and organics; while the Duke University laboratories covered the radium isotopic analysis $\left({ }^{223} \mathrm{Ra},{ }^{224} \mathrm{Ra},{ }^{228} \mathrm{Ra}\right.$, and $\left.{ }^{226} \mathrm{Ra}\right)$.

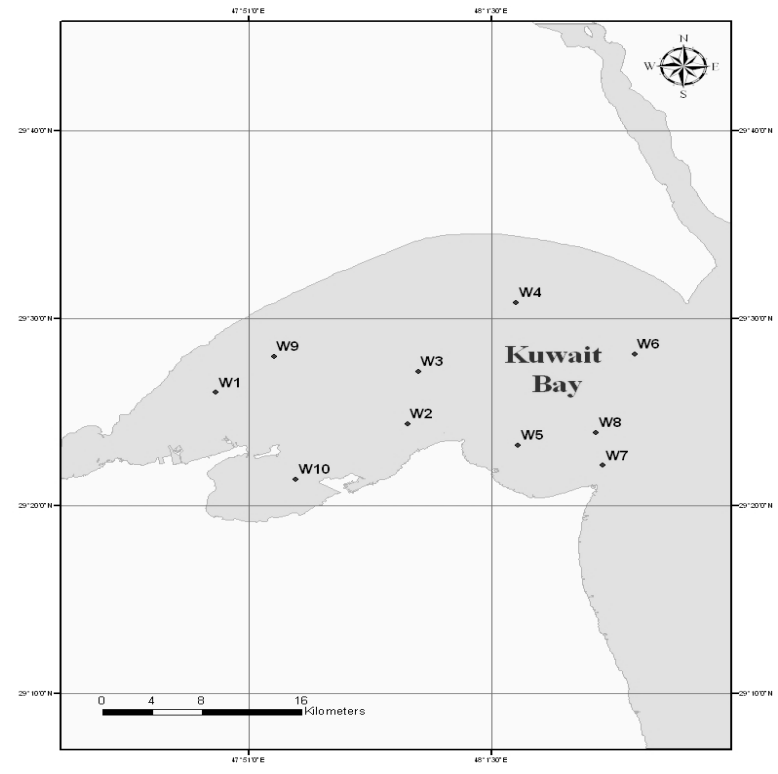

Figure 2: $\quad$ Sampling stations in KB.

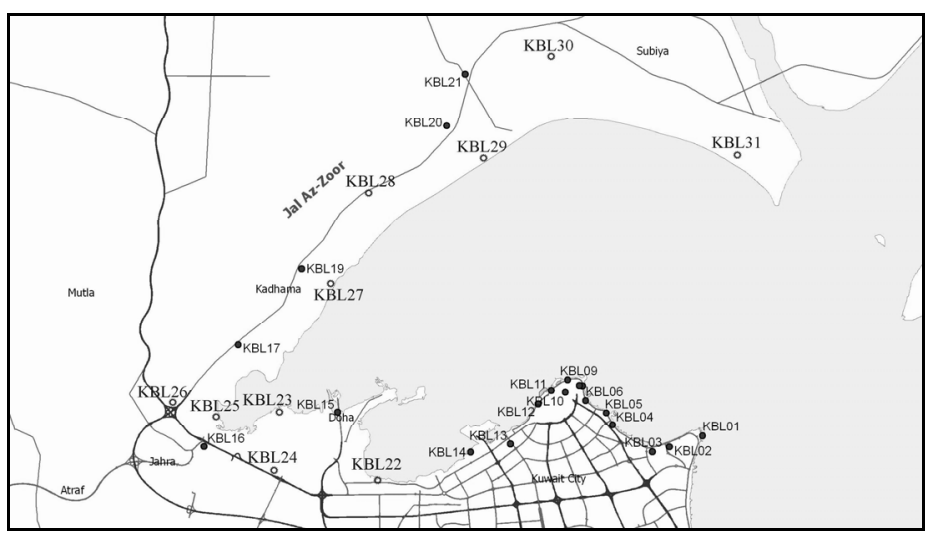

Figure 3: All groundwater sampling locations (existing and newly drilled wells. 


\section{Results}

The SGD to KB and the Kuwait coastline in the Arabian Gulf was estimated using radium as a tracer for groundwater. Estimates of SGD rates ranged from 1.1 to $2.8 \times 10^{7} \mathrm{~m}^{3} \mathrm{~d}^{-1}$ (55 to $150 \mathrm{~m}^{3} \mathrm{~m}^{-1} \mathrm{~d}^{-1}$ ) for $\mathrm{KB}$ and 0.65 to $1.3 \times 10^{7} \mathrm{~m}^{3} \mathrm{~d}^{-1}$ (65 to $125 \mathrm{~m}^{3} \mathrm{~m}^{-1} \mathrm{~d}^{-1}$ ) for the Arabian Gulf. The extreme aridity of the Arabian Gulf region has been a major factor in the setup of the radium budget. The dust storms, seawater evaporation and irrigation of landscapes and private gardens conditions should be taken into considerations whenever SGD is estimated. Analyses of groundwater samples showed that, the TDS, $\mathrm{HCO}_{3}, \mathrm{NO}_{3}, \mathrm{TOC}$, and total petroleum hydrocarbon (TPH) have average concentrations of $25,000 \mathrm{mg} / \mathrm{l}$, $136 \mathrm{mg} / \mathrm{l}, 62 \mathrm{mg} / 1,1 \mathrm{mg} / \mathrm{l}$ and $0.2 \mathrm{mg} / \mathrm{l}$, respectively. Except for nitrate, none of the major element concentrations seemed to be of significance to the elemental budget of the bay. Nitrate concentrations, on the other hand, do not stop at being significant, but extend to being alarming. Given the estimated SGD rates, an average of about 1060 tons of nitrate are delivered daily to the bay via SGD. It is noteworthy, that elevated nitrate concentrations is a natural phenomenon in the groundwater of Kuwait and nonetheless, the observed concentrations in urban area are even higher than the national average, probably due to leakages from fertilized excess irrigation water and sewerage network. Trace elements results for the groundwater were mostly below detection limits; however, strontium and boron had averages of 14 and $1.6 \mathrm{mg} / \mathrm{l}$, respectively. The concentrations of these last two elements translate into 234 and 27 tons/d of strontium and boron, respectively, reaching the bay via SGD, which could be of significance to the health of the bay.

The differences in values of the oceanographic variables between surface and bottom layers are not statistically significant for seawater temperature, salinity, turbidity, $\mathrm{pH}, \mathrm{TOC}$, oxygen, nutrients and chlorophyll (Student's t-test, $\mathrm{p}>0.05$; at $95 \%$ confidence interval). The nutrients, excluding ammonia, were correlated with each other (especially phosphates, nitrates and nitrites), and vary in the positive side of both principal components. Chlorophyll was correlated with turbidity, ammonia and temperature. Salinity and $\mathrm{pH}$ were highly positively correlated, while DO seemed to be distributed independently. Although these are approximate relations, it is clear, that salinity and temperature are oddly going in different directions and nutrients are negatively correlated with salinity. Most of the parameters in $\mathrm{KB}$ seemed to be related to seawater temperature, rather than with salinity (except for $\mathrm{pH}$ ).

\section{Conclusions}

Overall, lowest temperature, highest nitrate and highest chlorophyll- $a$ were recorded in the waters associated with the highest radium activities (W2 and W3). As groundwater is typically of lower temperature than surface water (i.e., in arid regions) and generally rich in nutrients (especially nitrate concentrations), these observations might be manifestations of SGD impacts on the water quality of the bay. In support of this last statement, temporal trends of the concentrations 
for most the measured parameters are in agreement with SGD's temporal trend, that is, increase with increasing seasonal temperature. Potential impacts on the productivity of the bay may be seen in the increase of the phytoplankton (chlorophyll-a) and zooplankton (specifically: protozoans and copepods) at locations where ${ }^{226} \mathrm{Ra}$ activity is elevated. Nonetheless, discharges of the sewerage system to the bay, and the low temperature/high nutrients Shatt AlArab waters may be responsible for some of the aforesaid signs.

\section{Recommendations}

The results of SGD quantification showed that $\mathrm{KB}$ is receiving groundwater flux that is above the average when compared to other locations in the world. Through such a flux, large mass of nutrients and pollutants are reaching the bay on daily bases. Nonetheless, the significance of these masses to the overall budget of the bay, and whether they are detrimental or beneficial to the wellbeing of the bay are relative, and can be determined only in the context of the hydrodynamic and biological conditions of the bay. Accordingly, it is recommended to conduct an overall budgeting of the bay's nutritional and elemental inputs and outputs. In such a study, the obtained estimates of nutritional and contaminants inputs to the bay through SGD should be utilized in the calculation of nonpoint sources to the KB.

\section{Acknowledgements}

The authors would like to extend their appreciation to the Kuwait Foundation for the Advancement of Sciences (KFAS) for partially funding the study. The unlimited support of the Kuwait Institute for Scientific Research (KISR) management was pivotal in carrying out the various tasks of the study. The authors would like to thank the staff of the Environment and Life Sciences Research Center (ELSRC) of KISR for their assistance in conducting the study. The study team would also like to thank the staff of the Duke University Laboratories, North Carolina, USA.

\section{References}

[1] Buddemeier, R. (ed.), 1996. Groundwater discharge in the coastal zone: Proceedings of an International Symposium. LOICZ/R\&S/96-8, 179 pp. LOICZ, Texel, Netherlands.

[2] Moore, W.S. and R. Arnold, 1996, Measurement of 223Ra and 224Ra in coastal waters using a delayed coincidence counter. Journal of Geophysical Research 101:1321-1329.

[3] Charette, M, K. Buesseler, and J. Andrews, 2000, Utility of radium isotopes for evaluating the input of groundwater-derived nitrogen to estuaries. Limnology and Oceanography 46:465-470. 
[4] Krest, J.M., W.S. Moore, L.R. Gardner, and J.T. Morris, 2000, Marsh nutrient export supplied by groundwater discharge: Evidence from radium measurements. Global Biogeochemical Cycles, 14:167-176.

[5] Charette, M.A. and K.O. Buesseler, 2004, Submarine groundwater discharge of nutrients and copper to an urban subestuary of Chesapeake bay (Elizabeth River). Limnology and Oceanography 49:376-385.

[6] Kelly, R.P. and S.B. Moran, 2002, Seasonal changes in groundwater input to a well-mixed estuary estimated using radium isotopes and implications for coastal nutrient budgets. Limnology and Oceanography 47:1796-1807.

[7] Charette, M.A., W.S. Moore, and W.C. Burnett, 2008,Uranium- and thorium-series nuclides as tracers of submarine groundwater discharge. In U-Th Series Nuclides in Aquatic Systems, Series: Radioactivity in the Environment, edited by S. Krishnaswami and J.K. Cochran. Amsterdam: Elsevier.

[8] Cable, J.E., W.C. Burnett, J.P. Chanton, and G.L. Weatherly, 1996, Estimating groundwater discharge into the northeastern Gulf of Mexico using radon-222. Earth and Planetary Science Letters 144:591-604.

[9] Burnett, W., J. Cable, D. Corbett, and J. Chanton, 1996, Tracing groundwater flow into surface waters using natural 222Rn. Proceedings of International Symposium on Groundwater Discharge in the Coastal Zone, Land-Ocean Interactions in the Coastal Zone (LOICZ), Moscow, July 610, pp. 22-28.

[10] Kontar, E. and W. Burnett, 1999, Study of groundwater discharge to the coastal zone and evaluation of potential earthquakes. Proceedings: International Conference on Marine Environment, the Past. Present and Future; National Sun Yat-Sen University, Kaohsiung, Taiwan, January 2628.

[11] Corbett D., J. Chanton, W. Burnett, K. Dillon, C. Rutkowski and J. Fourqurean, 1999, Patterns of groundwater discharge into Florida Bay. Limnology and Oceanography 44:1045-1055.

[12] Rama, and W.S. Moore, 1996, Using the radium quartet for evaluating groundwater input and water exchange in salt marshes. Geochimica et Cosmochimica Acta 60:4645-4652.

[13] Rakha K.A., K. Al-Salem, and S. Neelamani, 2007b, Hydrodynamic atlas for Kuwaiti territorial waters. Kuwait Journal of Science and Engineering.

[14] Al-Yamani, F., J.M. Bishop, E. Ramadhan, M. Al-Husaini, and A. AlGhadban, 2004, Oceanographic Atlas of Kuwait's Waters. Kuwait: Kuwait Institute for Scientific Research, $202 \mathrm{pp}$.

[15] Al-Yamani, F., A. Al-Ghunaim, D.V. Subba Rao, N. Khan, M. Al-Ghool, M. Muruppel, S. Al-Qatma, and M. Luis, 2000, Fish Kills, Red Tides, and Kuwait's Marine Environment. Kuwait: Kuwait Institute for Scientific Research (English and Arabic).

[16] Al-Yamani, F.Y., W. Ismail, K. Al-Rifaie, A. Mharzi, D.V.S. Rao, A. Lennox, T. Al-Saeed, A. Al-Ghadban, K. Al-Matrouk, M. Bahlool, and A. Al-Khabaz, 2002, Oceanographic and environmental assessment of 
Kuwait Bay in relevance to toxic algal blooms. Kuwait Institute for Scientific Research, Report No. KISR 6558, Kuwait.

[17] Al-Ghadban, A. and A. El-Sammak, 2005, Sources, distribution and composition of the suspended sediments, Kuwait Bay, Northern Arabian Gulf Journal of Arid Environment 60:647-661.

[18] Grealish G., S. Omar and M. Quinn, 2001, Oil Affected Area Soil SurveyAssessing Damage Magnitude and Recovery of the Terrestrial Eco-system - Follow-up of Natural and Induced Desert Recovery. Kuwait Institute for Scientific Research, Report No. KISR6290, Kuwait.

[19] Foda, M.A., F.I. Khalaf, and A.S. Al-Kadi, 1985, Estimation of dust fallout rates in the northern Arabian Gulf. Sedimentology 32:595-603. 